\title{
ANALISIS DESAIN PEMBELAJARAN PKN DI SD/MI KELAS TINGGI
}

\author{
Rora Rizky Wandini, Siti Maghfhirah, Ahmad Tarmizi Hasibuan \\ UIN Sumatra Utara Medan, UIN Sunan Kalijaga Yogyakarta, UIN Sunan Kalijaga \\ Yogyakarta \\ rorarizkiwandini@uinsu.ac.id, tmaghvirral@gmail.com, roszi0508@gmail.com
}

\begin{abstract}
Abstrak
Pendidikan kewarganegaraan mengajarkan siswa untuk mengetahui segala hal yang mencakup akan dirinya dan juga negaranya. Pada akhirnya, siswa akan diminta untuk menerapkan nilainilai dari mata pelajaran ini. Contohnya saja pada tema identitas nasional yang berarti identitas dari bangsa Indonesia yaitu pancasila. Dengan mengimplementasikan pancasila di kehidupan sehari-hari maka siswa berarti telah menunjukan identitas bangsa negaranya. Namun dalam hal ini, upaya untuk menerapkan PKn di kehidupan sehari-hari bukanlah hal yang mudah, oleh karena itu perlu bagi tenaga didik untuk menyiapkan desain pembelajaran PKn agar para siswa menikmati pelajaran tersebut dan memudahkan mereka untuk menerapkan kandungan dari nilai-nilai mata pelajaran PKn. Penulisan ini menggunakan metode studi literatur. Penulis mengumpulkan berbagai sumber data sebagai bahan acuan untuk dapat menyelesaikan tulisan ini. Adapun hasil penelitian dapat disimpulkan bahwa Desain Pembelajaran PKN di SD/MI Kelas Tinggi, 1) menggunakan media visual, 2) metode tanya jawab, 3) penggunaan media gambar, 4) penggunaan multimedia, 5) pendekatan pembelajaran aktif, kreatif, efektif, dan menyenangkan, 6) model course review horay dengan penggunaan power point, 7) penggunaan media pembelajaran, 8) penggunaan metode diskusi, 9) strategi pembelajaran aktif tipe crossword puzzle.
\end{abstract}

Kata kunci: Desain Pembelajaran, PKN, Kelas Tinggi.

Received: 2021- 6- 2 Accepted::2021-6-20 Published:2021-6-22

Citizenship education teaches students to know everything that includes themselves and their country. At the end, students will be asked to apply the values of this subject. For example, on theme national identity which means identity of Indonesian nation, namely Pancasila. By implementing Pancasila in everyday life, it means that the students have shown their national identity. However, in this case, the effort to apply PKn in daily life is not an easy thing, therefore it is necessary for students to prepare PKn learning designs so the students enjoy the lesson and make it easier for them to apply the content of PKn subject values. This study uses the literature study method. The author collects various data sources as reference material to complete this paper. The results of the study, it can be concluded that PKn Learning Design in Higher Class of SD/MI, 1) the use visual media, 2) the method of question and answer, 3) the use of Picture Media, 4) the use of Multimedia, 5) an active, creative, effective, and effective learning approach. fun, 6) Horay course review model by using power point, 7) the use of Learning Media, 8) the use of Discussion Method, 9) Active learning strategy of crossword puzzle type.

Keywords: Learning Design, PKn, Higher Class 


\section{A. PENDAHULUAN}

Kunci utama agar manusia dapat berkembang dan memiliki ilmu sehingga dapat bemanfaat bagi agamanya maupun negaranya adalah ilmu dan ia merupakan kebutuhan dasar bagi seseorang. ${ }^{1}$ Namun untuk mendapatkan sebuah ilmu, proses penyaluran antara guru dengan siswa perlu diperhatikan karena hal tersebut yang akan menjadikan kegiatan pembelajaran dapat atau tidak berjalan dengan baik. ${ }^{2}$ Pada sekolah dasar (SD) ataupun Madrasah Ibtidaiyah (MI), kelas dibagi menjadi dua jenis yaitu kelas rendah dan kelas tinggi. Adapun pembagianya bukan hanya sekedar pembatasan umur namun berkaitan pula dengan materi yang akan disampaikan. Proses pembelajaran menerapkan kurikulum suatu pendidikan institusi sehingga dapat mempengaruhi siswa untuk mencapai tujuan pendidikan yang ditetapkan. Hal ini bertujuan pendidikan menggerakkan siswa menuju perilaku, intelektual, moral dan sosial perubahan perilaku agar mampu hidup mandiri sebagai individu dan makhluk sosial untuk mencapai tujuan tersebut siswa berinteraksi dengan lingkungan belajar yang dikelola oleh guru melalui proses pembelajaran.

Hambatan kegiatan belajar dapat dipengaruhi oleh beberapa faktor diantaranya minimnya minat siswa dalam menyerap materi pelajaran, serta kurangnya siswa pemahaman dalam menerima materi yang disajikan. Ini karena guru hanya menggunakan metode ceramah dan buku teks. Oleh karena itu struktur pembelajaran harusnya di desain sebaik mungkin untuk membantu kegiatan pembelajaran antara guru dan siswa Sekolah Dasar. Desain dalam pembelajaran merupakan kebutuhan bagi setiap tenaga didik ${ }^{3}$ karena hal tersebut dapat menjadikan terlaksananya dengan baik proses pembelajaran. Ditinjau lagi, siswa terdiri dari berbagai macam jenis, mulai dari yang mudah paham pembelajaran hingga kepada siswa yang lambat menerima pembelajaran. Dengan desain yang sedemikian rupa, dapat meningkatkan minat belajar siswa ${ }^{4}$ dan kecenderungan mereka untuk kedatangan mata pelajaran PKn. Semakin siswa merasa senang dengan mata

\footnotetext{
${ }^{1}$ Kustiana Arisanti, Ilmu Pengetahuan Sebagai Pilar Peradaban, Humanistika: Jurnal Keislaman 4, No. 1, 2018, hlm.77-90, Https://Doi.Org/10.36835/Humanistika.V4i1.31.

${ }^{2}$ Wahyu Iskandar, Kemampuan Guru Dalam Berkomunikasi Terhadap Peningkatkan Minat Belajar Siswa Di Sdit Ummi Darussalam Bandar Setia, Ar-Riayah: Jurnal Pendidikan Dasar 3, No. 2, 2019, hlm.135, Https://Doi.Org/10.29240/Jpd.V3i2.1126.

${ }^{3}$ Rumidjan Et Al., Pelatihan Pembuatan Media Grafis Dan Media Papan Untuk Meningkatkan Kualitas Pembelajaran Bagi Guru Sekolah Dasar, Abdimas Pedagogi 1, No. 1, 2017, hlm.77-81.

${ }_{4}$ Adib Rifai Setiawan, Desain Pembelajaran Untuk Membimbing Siswa Sekolah Dasar Dalam Memperoleh Literasi Saintifik, April 2020, Https://Doi.Org/10.35542/Osf.Io/U59f8.
} 
pelajaran $\mathrm{PKn},{ }^{5}$ maka siswa akan semakin menunggu kedatangan hari untuk mata pelajaran tersebut.

Atas dasar itulah penulis melakukan analisis terhadap desain pembelajaran PKn kelas tinggi di tingkat sekolah dasar atau Madrasah Ibtidaiyah. Peneliti berasumsi bahwa siswa di Sekolah Dasar berada pada tahap pertumbuhan dan perkembangan. Pastinya masih memiliki kepribadian yang labil. Dalam pembelajaran, siswa diharapkan dapat berinteraksi dengan guru maupun siswa lain sehingga suatu proses pembelajaran dapat lebih natural untuk memperoleh hasil yang diinginkan guna mencapai tujuan sesuai dengan kebutuhan yang akan dihasilkan. Media pembelajaran merupakan salah satu komponen pembelajaran yang memiliki peran vital dalam pembelajaran.

Penggunaan media pembelajaran pada tahap orientasi pembelajaran akan membantu efektivitas proses pembelajaran dalam menyampaikan pesan dan isi pelajaran saat itu. Menurut Gagne dalam Siregar dan Nara selain dapat membangkitkan motivasi dan minat siswa, jenis-jenis media yang digunakan dalam proses pembelajaran dan pelatihan cukup beragam, nilainya sederhana media ke media yang kompleks dan canggih. Gagne juga menyatakan bahwa belajar adalah suatu peristiwa yang dilakukan secara hatihati untuk mewujudkan pembelajaran dan menjadikannya bermanfaat. ${ }^{6}$

\section{B. Metode Penelitian}

Penelitian ini menggunakan metode studi literatur. Metode studi literatur ini digunakan oleh penulis untuk mengumpulkan berbagai penjelasan dan pembahasan yang berkaitan dengan desain pembelajaran PKn kelas tinggi dan mengandalkan bibliografi dari berbagai sumber seperti buku dan artikel ilmiah yang dianggap relevan dengan tajuk pembahasan. Dalam pengumpulan data penulis menggunakan data pustaka dengan cara membaca, menelaah serta menganalisis bahan penelitian desain pembelajaran Pkn kelas tinggi yang dipaparkan secara detail. Pendekatan yang digunakan dalam penelitian ini adalah pendekatan kualitatif dengan mendeskripsikan atau menuangkan hasil analisis penulis. ${ }^{7}$ Penelitian kualitatif merupakan penelitian naturalistik karena penelitiannya

\footnotetext{
5 Zinnurain And Abdul Gafur, Jurnal Inovasi Teknologi Pendidikan, Jurnal Inovasi Teknologi Pendidikan 2, No. 2, 2015, hlm. 157-68, Http://Journal.Uny.Ac.Id/Index.Php/Jitp\%0apengembangan.

${ }^{6}$ Evalina Siregar, Nara, Teori Belajar dan Pembelajaran, Bogor :Ghalia Indonesia, 2011.

${ }^{7}$ Sugiyono, Metodelogi Penelitian Pendidikan, Bandung: Alfabeta, 2012.
} 
dilakukan pada kondisi sebenarnya. ${ }^{8}$ Penelitian kualitatif dilakukan dengan membuat deskripsi, gambaran sistematis, faktual dan akurat mengenai fakta-fakta, sifat-sifat serta hubungan antara berbagai fenomena yang diteliti secara mendalam. ${ }^{9}$

Page | 62

\section{Hasil dan Pembahasan}

Pendidikan pada masa kini di Sekolah Dasar menggunakan pembelajaran tematik. Adapun yang dimaksud dengan pembelajaran tematik adalah sebuah model yang mengacu pada tema yang sudah ditentukan dan dikombinasikan pula dengan kompetensi dasar dengan sedemikian rupa yang harus dicapai. ${ }^{1}$ Untuk melaksanakan kegiatan pembelajaran, maka diperlukan sebuah desain yang menarik dan menyenangkan bagi siswa ditambah lagi, keluarnya permendiknas nomor 22 tahun 2006 tentang standar isi yang menjadikan mata pelajaran PKn agar dapat menjadikan warga negaranya untuk sadar hukum dan sadar akan jati diri negaranya termasuk akan hak dan kewajibannya. ${ }^{2}$ Selain itu Peraturan Menteri Pendidikan dan Kebudayaan Republik Indonesia Nomor 24 Tahun 2016 menyampaikan bahwa pembelajaran di sekolah dasar dilaksanakan menggunakan model tematik. Pembelajaran tematik adalah metode pembelajaran yang menekankan pemberian tema khusus pilihan untuk mengajarkan beberapa konsep berdasarkan paduan penggunaan ragam informasi ketika mempelajari topik tertentu. ${ }^{10}$

Pada era teknologi informasi sekarang ini sangat berkorelasi dengan ketersediaan informasi yang semakin bervariasi dan tersedia dalam berbagai bentuk dan dalam waktu yang relatif cepat. Kemajuan teknologi telah memberikan beberapa kelebihan karena dapat digunakan hampir di semua bidang kehidupan manusia, salah satunya dalam bidang pendidikan utama selama proses pembelajaran. Dengan pesatnya perkembangan media informasi dan komunikasi, baik perangkat keras (Hardware) dan perangkat lunak (Software). Perkembangan tersebut membuat pergeseran peran guru. Guru tidak lagi berperan sebagai satu-satunya sumber informasi dalam proses pembelajaran.

8 Fitria Martanti, Peran Guru Kelas Dalam Memberikan Layanan Bimbingan Konseling di SDN Watuaji01KabupatenJepara,Magistra,6(2015), <https://publikasiilmiah.unwahas.ac.id/index.php/MAGISTRA/arti cle/view/1776\%0D>. hlm 27

9 Fitria Martanti, Metode Struktural Analitik Sintetik dalam Pembelajaran Anak Dislikesia.AlBidayah,vol.10 No.1, 2018, hlm.23

${ }^{10}$ Resor, C. W. Investigating Family, Food, and Housing Themes in Social Studies. Maryland: Rowman \& Littlefield Publishers, 2017. 
Peran guru dalam konteks pembelajaran mengalami perubahan, di mana guru dituntut untuk dapat bekerja secara profesional, mengajar secara profesional sistematis, berdasarkan prinsip pembelajaran yang efektif dan efisien, Artinya, guru dapat merekayasa media pembelajaran tersebut sehingga menjadi sebuah proses belajar sebagai pengalaman pengalaman bagi siswa. Guru diharapkan memiliki kemampuan untuk: (a) memanfaatkan sumber belajar di lingkungan secara optimal dalam proses pembelajaran, (b) berkreasi dan mengembangkan ide-ide baru, (c) mengurangi pengetahuan seseorang diperoleh siswa dari sekolah dengan ilmu yang akan diperoleh kemudian di komunitas, (d) memperjelas relevansi dan relevansi subjek bidang ilmu dengan kebutuhan sehari-hari di masyarakat, (e) berkembang pengetahuan, keterampilan, dan perilaku peserta didik secara bertahap dan utuh, (f) memberikan kesempatan kepada siswa untuk dapat berkembang secara bertahap optimal sesuai kemampuannya, (g) menerapkan prinsip belajar aktif.

Adapun beberapa desain pembelajaran untuk pembelajaran PKn di SD/MI kelas tinggi seperti penjelasan di atas bahwa dominasi dari desain pembelajaran PKn kelas tinggi berupa media yang kompatibel pada era saat ini. Adapun beberapa yang penting untuk dipaparkan terkait desain pembelajaran Pkn kelas tinggi dilihat dari penggunaan mediavisual, metode, media bergambar, multimedia, pendekatan pembelajaran serta model-model yang relevan. Hal ini dipaparkan di bawah sebagai berikut:

\section{Menggunakan Media Visual}

Media visual adalah suatu metode dalam menyampaikan pembelajaran dengan memanfaatkan alat-alat peraga sehingga siswa dapat melihat menggunakan indra penglihatan mereka. ${ }^{11}$ Dengan menggunakan media visual siswa dapat dilatih agar menggunakan kemampuan mengingat, mengucapkan kembali yang diketahui, dan juga bertindak untuk mengambil dan memutuskan yang benar. ${ }^{12}$ Model belajar seperti ini akan dapat meningkatkan minat belajar siswa dan menguji kemampuan mereka secara bertahap. Guru pun dapat mengajak siswanya untuk berpikir lebih dalam, sehingga peran besar bukan hanya tertuju pada guru yang monoton menyampaikan materi namun keaktifan siswa menjadi sangat dibutuhkan untuk metode jenis ini. Tapi tetap

11 Maimunah Maimunah, Metode Penggunaan Media Pembelajaran, Al-Afkar: Jurnal Keislaman \& Peradaban 5, No. 1, 2016, https://doi.org/10.28944/afkar.v5i1.107.

12 Pilemon Poly Maroa, Charles Kapile, and Abdul Hamid, Penerapan Pembelajaran PKn Dengan Media Visual Untuk Meningkatkan Hasil Belajar Pada Siswa Kelas V SD Inpres 012 Bajawali Kecamatan Lariang Kabupaten Mатијu Utara, Jurnal Kreatif Tadulako Online 3, no. 2, 2014, hlm.84-93. 
saja, semua hal memiliki titik lemah. Kesulitan dalam media visual ini adalah penyediaan alat peraga, sehingga bila tidak ada alat peraga maka metode pembelajaran jenis ini tidak akan dapat terlaksana. ${ }^{13}$

2. Metode Tanya Jawab

Sutikno mengartikan metode tanya jawab sebagai sebuah metode belajar dengan menyajikan berbagai pertanyaan yang ditujukan pada siswa dan harus memiliki jawaban. Namun dalam ruang lingkupnya, yang dapat bertanya bukan hanya guru kepada siswa namun juga, siswa dapat memberikan sebuah pertanyaan kepada guru untuk dijawab. Dengan kemampuan siswa menjawab pertanyaan guru dengan tepat, maka guru dapat melihat seberapa besar pemahaman siswa akan materi yang telah ataupun yang akan diajarkannya. ${ }^{14}$

3. Penggunaan Media Gambar

Pada hakikatnya, media gambar termasuk media visual karena dapat diamati secara langsung dan juga dapat diindrakan. ${ }^{15}$ Sedangkan untuk fungsinya sendiri, media ajar memiliki 5 hal yang perlu diperhatikan diantaranya: Pertama, dengan penggunaan media, kita dapat membuat suasana yang nyaman dan menyenangkan dalam pembelajaran. Kedua, dalam penggunaan media, maka harus tetap memerhatikan tujuan pembuatan media dan keselarasan media dengan materi yang disampaikan. Ketiga, media pembelajaran tujuan utamanya bukanlah sekedar menghibur dan bermain namun sebagai pelengkap proses pembelajaran. Keempat, dengan adanya media, maka diharapkan siswa dapat memahami materi dengan mudah sehingga materi akan dapat dilanjutkan tanpa mengesampingkan pengetahuan siswanya. Keenam, mutu dan minat belajar siswa merupakan tujuan utama pembuatan media pembelajaran. ${ }^{16}$

Namun pada umumnya semua memiliki kelebihan dan kekurungan. Adapun kelebihanya adalah jelas sifatnya ketika memunculkan sebuah masalah, tidak terbatas

13 Guallichico Mayra, Penggunaan Media Visual Dalam Proses Pembelajaran, Journal Of Chemical Information And Modeling 53, No. 9, 2013, hlm.1689-99.

${ }^{14}$ M. Sobry Sutikno, Belajar Dan Pembelajaran, Upaya Kreatif Dalam Mewujudkan Pembelajaran Yang Berhasil., Lombok: Holistica, 2013.

${ }^{15}$ Fitria Tri; dkk Wardani, Penggunaan Media Gambar Untuk Meningkatkan Pemahaman Siswa Pada Mata Pelajaran Sosiologi, Jurnal Pendidikan Dan Pembelajaran 2, no. 3, 2013, hlm. 1-12.

16 Nina Sundari, Penggunaan Media Gambar Dalam Meningkatkan Keaktifan Siswa Dalam Pembelajaran Pengetahuan Sosial Di Sekolah Dasar, EduHumaniora | Jurnal Pendidikan Dasar Kampus Cibiru 5, no. 1, 2016, https://doi.org/10.17509/eh.v5i1.2836. 
ruang maupun waktu, kemampuan mengamati siswa dapat dilihat. Kekurangannya adalah hanya bisa mengamati dengan indra penglihatan, Semua siswa dapat memunculkan persepsi dan mungkin saja terdapat banyak perbedaan di dalamnya, semakin kecil gambar maka semakin sedikit siswa yang dapat mengamati. ${ }^{17}$

4. Penggunaan Multimedia

Pada era sekarang, kemudahan untuk menyampaikan pembelajaran sudah kita alami, sumber yang menyajikan model pembelajaran yang kreatif juga sangat sering kita jumpai. Yang dimaksudkan multimedia adalah sebuah media yang mencakup beberapa hal, padanya bisa terdapat gambar, suara, tulisan berupa teks, dan beberapa hal lainnya. Pembuatan media pembelajaran juga sangat mudah dilakukan, bisa melalui android atau IOS maupun laptop/komputer. Kita cukup menyediakan beberapa hal penting dalam sebuah pembelajaran. Misalnya tema yang akan kita buat adalah identitas negara. Kita dapat mencantumkan gambar pancasila, pengertianpengertiannya menurut para tokoh dan bisa ditambah dengan materi yang ingin disampaikan sesuai tema pembahasan. Pada video yang akan disajikan, dapat diselipkan teks sekaligus salinan dari audio, sehingga para siswa bisa mendengar sekaligus membaca materi.

5. Pendekatan Pembelajaran Aktif, Kreatif, Efektif, dan Menyenangkan.

Aktif menurut Soediono adalah bentuk pembelajaran dengan menjadikan siswa dan guru berperan penting. Peran guru agar dapat membuat suasana belajar yang nyaman dan siswa berperan dengan aktif bertanya maupun menyampaikan gagasan atau ide yang dimilikinya. ${ }^{18}$ Dalam hal ini, guru hanyalah fasilitator agar siswanya mendapat kemudahan dalam belajar. Guru akan mengarahkan proses pembelajaran sedangkan siswa aktif dalam kegiatan pembelajaran.

Kreatif adalah kemampuan guru untuk menyiapkan media pembelajaran sesuai dengan materi yang akan disampaikan dan melalui media tersebut siswa dengan mudah

17 Wahyu Bagja Sulfemi and Hilga Minati, Meningkatkan Hasil Belajar Peserta Didik Kelas 3 Sd Menggunakan Model Picture and Picture Dan Media Gambar Seri, Jurnal Pendidikan Sekolah Dasar 4, no. 2, 2018, hlm.228, https://doi.org/10.30870/jpsd.v4i2.3857.

${ }^{18}$ Sundari, Penggunaan Media Gambar Dalam Meningkatkan Keaktifan Siswa Dalam Pembelajaran Pengetahuan Sosial Di Sekolah Dasar.” 
memahami yang disampaikan. ${ }^{19}$ Untuk mencapai kreatif, maka perlu melalui 4 tahapan sebagai berikut: Pertama, Tahapan persiapan, tahap ini adalah tahapan yang di dalamnya terdapat kegiatan pengenalan masalah, pengumpulan data, dan penyediaan jawaban sementara yang berkaitan dengan masalah yang tersedia. Kedua, Tahapan pematangan berupa pemberian penjelasan, disertai dengan pembatasan masalah agar dapat dikerucutkan dan tidak melebar kemana-mana sehingga dapat sesuai dengan tema. Ketiga, Tahapan pemahaman merupakan tahapan pemecahan masalah dengan mengumpulkan berbagai informasi yang valid. Keempat, Tahapan pengetesan adalah tahapan pembuktian hipotesis. Siswa akan disebut sebagai siswa kreatif bila ia memiliki kemampuan untuk menyelesaikan masalah dengan metode yang baru maupun melalui kegiatan yang baru. ${ }^{20}$

Sebuah pembelajaran dapat dikatakan efektif apabila kegiatan tersebut dapat terwujud sebagaimana seharusnya baik dari tata cara hingga ke tujuan pembelajaran tersebut. Menurut Murphy, pembelajaran dapat dikatakan efektif apabila memenuhi tiga syarat, yaitu: (1) peserta didik diarahkan untuk memahami hakikat belajar, (2) pembelajarannya bekerjasama antara siswa dan guru, (3) peran utama dipegang oleh siswa, sedangkan guru hanya pembimbing. ${ }^{21}$

Faizah mengaitkan menyenangkan dengan sudut sebuah perasaan. Guru dituntut untuk mengubah sebuah rasa suka ke perasaan percaya diri sehingga siswa akan menganggap dirinya bisa mempelajari materi yang disampaikan. Dalam mengubah rasa suka terebut maka harus diiringi dengan sikap yang ramah, suka senyum, dan mampu menjadikan suasana perbincangan dengan santun. Selain itu guru juga meski adil kepada semua siswanya dan bersabar ketika menghadapi berbagai perilaku siswanya tersebut.

6. Model course review horay dengan penggunaan powerpoint

Menurut Dariyanto, penggunaan powerpoint memiliki beberapa kelebihan diataranya:

a) Bentuk sajiannya menarik karena dapat dibentuk dengan warna-warna menarik, animasi maupun gambar.

\footnotetext{
${ }^{19}$ Renee Hobbs, Non-Optimal Uses of Video in the Classroom, Learning, Media and Technology 31, no. 1, 2006, hlm.35-50, https://doi.org/10.1080/17439880500515457.

${ }^{20}$ D. M. Sari, M. Ikhsan, and Z. Abidin, The Development of Learning Instruments Using the Creative Problem-Solving Learning Model to Improve Students' Creative Thinking Skills in Mathematics, Journal of Physics: Conference Series 1088, 2018, https://doi.org/10.1088/1742-6596/1088/1/012018.

${ }^{21}$ Practice, Pedagogy and Policy: The Caroline Murphy, 2012.
} 
b) Dapat merangsang siswa untuk mengetahui bahan ajar yang tersedia

c) Pesannya mudah dipahami karena menggunakan poin-poin penting pembahasan

d) Tenaga didik tidak perlu repot untuk menjelaskan panjang lebar terhadap bahan yang disajikannya

e) Dapat dibuat sesuai kebutuhan dan dipakai berkali-kali

f) Dapat disimpan dan praktis ${ }^{10}$

Untuk dapat menerapkan model pembelajaran jenis ini, dapat mengikuti tahapan- tahapan berikut ini:

a) Guru menunjukkan standar kompetensi sekaligus melakukan pembahasan terhadap topik bahasan

b) Guru melakukan presentasi terhadap materi bahan dengan menggunakan powerpoint dan bantuan LCD

c) Meminta siswa untuk membuat kelompok dengan batasan kelompok, empat hingga lima siswa

d) Setiap kelompok diminta untuk membuat kotak dan dinomori, serta contoh pembuatan kotak ditampilkan melalui powerpoint

e) Pembacaan soal dan penulisan jawaban di kotak yang sudah disediakan masingmasing kelompok

f) Mendiskusikan kembali jawaban atas pertanyaan yang diberikan oleh guru setelah semua pertanyaan tersampaikan

g) Untuk jawaban yang benar maka kelompok mendapat tanda check list (v) dan langsung meneriakkan "horee!"

h) Merekap semua hasil jawaban yang benar dan teriakan "horee!" terbanyak

i) Kelompok dengan nilai tertinggi berhak mendapat reward

j) Untuk menguji kembali pengetahuan siswa, guru melakukan evaluasi terhadap siswa dengan memberikan beberapa pertanyaan ${ }^{22}$

7. Penggunaan media pembelajaran

Penggunaan media dapat mempengaruhi ingatan siswa akan mata pelajaran yang telah dilaluinya, ditambah lagi jika media tersebut disajikan dengan bentuk yang

22 Alice Udvari-Solner, Joyful Learning, Encyclopedia of the Sciences of Learning 3, no. 3, 2012, hlm.1665-67, https://doi.org/10.1007/978-1-4419-1428-6_795. 
menarik dan akan memberikan rasa senang kepada siswa itu sendiri sehingga akan berkesan pada siswa tersebut dan menunjang keberhasilannya dalam memahami materi yang disampaikan. Tuntutan terhadap media pembelajaran pun bukan hanya satu, melainkan ada tiga tuntutan yang harus dipenuhi oleh media pembelajaran agar media tersebut dapat memunculkan motivasi diri siswa. Adapun tiga motivasi tersebut adalah sebagai berikut:

a) Kemampuan media dalam menyediakan sebuah objek maupun menyimpannya

b) Kemampuan media dalam menyampaikan objek dengan berbagai bentuk yang sesuai dengan kebutuhan pembelajaran

c) Kemampuan media untuk menunjukkan berbagai kejadian yang sarat akan makna

Dengan penyediaan media yang menarik minat belajar siswa akan dapat menumbuhkan niat siswa untuk mengikuti pembelajran dengan baik hingga kegiatan pembelajaran berakhir. ${ }^{23}$

8. Penggunaan metode diskusi

Metode diskusi dinilai mampu merangsang siswa sehingga mengeluarkan pendapat dan menjadi aktif dalam proses pembelajaran. Dengan metode ini, siswa dituntut agar mampu berinteraksi dengan siswa lain maupun dengan gurunya sendiri. ${ }^{24}$ Namun metode ini memiliki kelemahan dan juga kelebihan diantaranya:

1) Kelebihan

a) Melibatkan seluruh siswa

b) Masing-masing siswa dapat menguji pemateri dalam hal penguasaan materi yang dikuasainya

c) Metode ini menumbuhkan sikap ilmiah

d) Dengan kemampuan siswa untuk mempertahankan argumen diharapkan agar dapat memunculkan rasa percaya diri siswa

e) Dapat dijadikan sebagai bahan untuk menampilkan demokratis siswa

2) Kekurangan

a) Kondisi keaktifan diskusi tidak dapat dipastikan karena bergantung pada no. 3,2020 .

${ }^{23}$ Dkk. Saodah, Penggunaan Media Dalam Pembelajaran PKn SD, Jurnal Pendidikan Dan Dakwah 2,

${ }^{24}$ Rizal. Andriani, Anthonius Palimbong, Meningkatkan Hasil Belajar Siswa Pada Pembelajaran PKn Kelas V Melalui Metode Diskusi Di SDN No. 1 Loli Dondo, Elementary School of Education E-Journal 2, no. 1 2014. 
pembawaan ketua kelompok beserta anggotanya

b) Untuk menjalankan diskusi maka siswa diharapkan terampil walau ia belum mengerti bagaimana penguasaan metode diskusi yang sebenarnya

c) Bisa saja diskusi hanya dikuasai oleh orang yang berani saja. Sehingga yang sering mengajukan pendapat ataupun memberi tanggapan orangnya tidak berganti dan terkesan "itu-itu saja"

d) Tidak semua topik dapat didiskusikan. Yang dapat didiskusikan hanyalah sebuah topik yang berupa masalah untuk mencairkan masalah tersebut dengan mencari solusinya

e) Jika sudah merasa nyaman dengan materi maka siswa mudah memberi tanggapan atau lainnya, namun bila tidak demikian biasanya akan sulit untuk dapat menyelesaikan permasalahan yang diajukan

f) Sering ditemui pada saat diskusi siswa tidak memiliki keberanian untuk menyampaikan argumennya

g) Jumlah siswa akan berpengaruh pada kesempatan yang dimiliki untuk menyampaikan argumen. Semakin banyak siswa maka semakin sedikit kesempatan untuk terus memberikan argumen

h) Waktu yang diperlukan untuk berdiskusi cukup panjang. Bisa saja sebuah masalah belum terselesaikan akibat dari pembatasan waktu yang dilakukan

Ada beberapa metode untuk melaksanakan motode diskusi, penulis mengambil metode yang dikemukakan oleh Suryosubroto, diantaranya sebagai berikut:

1) Tahapan diawali dengan penyampaian masalah yang dilakukan oleh guru sekaligus arahan berupa langkah-langkah pemecahan masalah. Atau siswa dan guru menetapkan bersama akan masalah yang ingin dijadikan topik bahasan.

2) Melalui instruksi guru, siswa diperintah membuat beberapa kelompok untuk berdiskusi.

3) Siswa mendiskusikan masalah yang tersedia kepada kelompok mereka masingmasing, adapun guru akan berkeliling untuk mengamati proses penyelesaian masalah yang disediakan oleh masing-masing kelompok.

4) Setelah selesai berdiskusi, maka kelompok harus menyampaikan hasil diskusi mereka. Untuk kelompok pendengar, mereka bertugas untuk memberi tanggapan 
atas hasil diskusi kelompok yang lain. Fungsi guru adalah sebagai penengah bila terdapat kesalahan dalam proses diskusi maupun dalam hasil diskusi.

5) Terakhir, setiap siswa mencatat hasil diskusi mereka dan memberikan hasil laporan mereka kepada guru agar dijadikan ke dalam "file" kelas. ${ }^{25}$

9. Strategi pembelajaran aktif tipe crossword puzzle

Dewi mengartikan crossword puzzle sebagai sebuah strategi yang mengajak siswa mengingat ulang materi yang telah dibahas sebelumnya dan akhirnya dapat memberikan pengaruh untuk hasil belajar yang akan diterima siswa. Metode ini dapat meningkatkan minat belajar siswa tanpa mengurangi proses pembelajaran yang sedang berlangsung. ${ }^{26}$ Adapun menurut Indriawati, yang dimaksud strategi crossword puzzle adalah metode yang menggabungkan dua buah proses sekaligus antara belajar dengan bermain. Tugas siswa tidak hanya berpatokan pada bermain teka-teki silang namun mempelajari materi dari teka-teki silang yang disiapkan. Dengan demikian siswa akan lebih tertarik untuk mengikuti pembelajaran. Tidak bisa dipungkiri bahwa metode pembelajaran crossword puzzle memiliki banyak manfaat. Namun beberapa diantaranya terdapat kekurangan dari metode jenis ini, yaitu: Anggapan siswa bahwa metode ini hanyalah metode permainan sehingga banyak diantara mereka tidak serius mengerjakan crossword puzzle ini dan metode ini hanya mengukur siswa dalam bentuk hapalan sehingga pemahaman siswa akan menganalisis menjadi tidak diperhatikan.

\section{SIMPULAN}

Berdasarkan pemaparan di atas dapat dipahami bahwa desain pembelajaran PKn SD/MI kelas tinggi didominasi oleh media yang kompatibel pada era saat ini. Adapun beberapa yang penting untuk dipaparkan terkait desain pembelajaran PKn SD/MI kelas tinggi dilihat dari penggunaan media visual, metode, media bergambar, multimedia, pendekatan pembelajaran serta model-model yang relevan. Desain pembelajaran yang baik tidak hanya berfokus pada metode dan model saja, namun secara kolektif memiliki banyak variasi yang terlibat seperti penjelasan di atas. Semua komponen penting itu harus terkombinasi dengan baik dalam pembelajaran. Termasuk pembelajaran $\mathrm{PKn}$ pada jenjang SD/MI. Pada penerapannya alangkah baiknya, dalam pembelajaran PKn menerapkan seluruh komponen desain pembelajaran di atas. Sehingga guru tidak akan

\footnotetext{
${ }^{25}$ Suryo Subroto., Proses Belajar Mengajar Di Sekolah, Jakarta: PT. Rineka Citra, 2009.

${ }^{26}$ Dewi M. N., Penerapan Strategi Pembelajaran Crossword Puzzle Untuk Meningkatkan, 2017, n.d.
} 
monoton dengan cara mengajar yang sama. Perbaikan dalam pembelajaran ketika menerapkan seluruh komponen di atas dapat membentuk keceriaan, ketertiban, pemahaman, minat dan semangat para siswa atau siswi untuk terus belajar yang disebabkan adanya pembaruan dan variasi yang dilakukan pada pembelajaran.

\section{DAFTAR PUSTAKA}

Andriani, Anthonius Palimbong, Rizal, Meningkatkan Hasil Belajar Siswa Pada Pembelajaran PKn Kelas V Melalui Metode Diskusi Di SDN No. 1 Loli Dondo. Elementary School of Education E-Journal 2, no. 1, 2014.

Hobbs, Renee. Non-Optimal Uses of Video in the Classroom. Learning, Media and Technology 31, no. 1, 2006, https://doi.org/10.1080/17439880500515457.

Iskandar, Wahyu. Kemampuan Guru Dalam Berkomunikasi Terhadap Peningkatkan Minat Belajar Siswa Di SDIT Ummi Darussalam Bandar Setia. AR-RIAYAH: Jurnal Pendidikan Dasar 3, no. 2, 2019, https://doi.org/10.29240/jpd.v3i2.1126.

Kustiana Arisanti. Ilmu Pengetahuan Sebagai Pilar Peradaban. HUMANISTIKA: Jurnal Keislaman 4, no. 1, 2018, https://doi.org/10.36835/humanistika.v4i1.31.

Maimunah, Maimunah, Metode Penggunaan Media Pembelajaran. Al-Afkar: Jurnal Keislaman \& Peradaban 5, no. 1, 2016. https://doi.org/10.28944/afkar.v5i1.107.

Maroa, Pilemon Poly, Charles Kapile, and Abdul Hamid. Penerapan Pembelajaran PKn Dengan Media Visual Untuk Meningkatkan Hasil Belajar Pada Siswa Kelas V SD Inpres 012 Bajawali Kecamatan Lariang Kabupaten Mamuju Utara, Jurnal Kreatif Tadulako Online 3, no. 2, 2014.

Martanti, Fitria, Peran Guru Kelas Dalam Memberikan Layanan Bimbingan Konseling di SDNWatuaji01KabupatenJepara,Magistra,6(2015), <https://publikasiilmiah.unwahas.ac. id/index.php/MAGISTRA/article/view/1776\%0D>.

Martanti, Fitria, Metode Struktural Analitik Sintetik dalam Pembelajaran Anak Dislikesia.AlBidayah,vol.10 No.1, 2018.

Mayra, Guallichico, “済無No Title No Title.” Journal of Chemical Information and Modeling 53, no. 9, 2013.

N., Dewi M. Penerapan Strategi Pembelajaran Crossword Puzzle Untuk Meningkatkan. 2017.

Practice, Pedagogy and Policy: The Caroline Murphy, 2012.

Rumidjan, Sumanto, Sukamti, and Sri Sugiharti. Pelatihan Pembuatan Media Grafis Dan 
Media Papan Untuk Meningkatkan Kualitas Pembelajaran Bagi Guru Sekolah Dasar, Abdimas Pedagogi 1, no. 1, 2017.

Resor, C. W. Investigating Family, Food, and Housing Themes in Social Studies. Maryland: Rowman \& Littlefield Publishers, 2017.

Saodah, Dkk. Penggunaan Media Dalam Pembelajaran PKn SD. Jurnal Pendidikan Dan Dakwah 2, no. 3, 2020.

Sari, D. M., M. Ikhsan, and Z. Abidin. The Development of Learning Instruments Using the Creative Problem-Solving Learning Model to Improve Students' Creative Thinking Skills in Mathematics. Journal of Physics: Conference Series 1088, 2018. https://doi.org/10.1088/1742-6596/1088/1/012018.

Setiawan, Adib Rifqi, Desain Pembelajaran Untuk Membimbing Siswa Sekolah Dasar Dalam Memperoleh Literasi Saintifik, no. April $2020 \quad$ (2020). https://doi.org/10.35542/osf.io/u59f8.

Siregar Evalina, Nara. Teori Belajar dan Pembelajaran, Bogor: Ghalia Indonesia, 2011

Subroto., Suryo. Proses Belajar Mengajar Di Sekolah. Jakarta: PT. Rineka Citra, 2009.

Sugiyono. Metodelogi Penelitian Pendidikan. Bandung: Alfabeta, 2012.

Sulfemi, Wahyu Bagja, and Hilga Minati, Meningkatkan Hasil Belajar Peserta Didik Kelas 3 Sd Menggunakan Model Picture and Picture Dan Media Gambar Seri. Jurnal Pendidikan Sekolah Dasar 4, no. 2 (2018): 228. https://doi.org/10.30870/jpsd.v4i2.3857.

Sundari, Nina. Penggunaan Media Gambar Dalam Meningkatkan Keaktifan Siswa Dalam Pembelajaran Pengetahuan Sosial Di Sekolah Dasar. EduHumaniora | Jurnal Pendidikan Dasar Kampus Cibiru 5, no. 1, 2016. https://doi.org/10.17509/eh.v5i1.2836.

Sutikno, M. Sobry. Belajar Dan Pembelajaran, Upaya Kreatif Dalam Mewujudkan Pembelajaran Yang Berhasil. Lombok: Holistica, 2013.

Udvari-Solner, Alice, Joyful Learning. Encyclopedia of the Sciences of Learning 3, no. 3, 2012, https://doi.org/10.1007/978-1-4419-1428-6_795.

Wardani, Fitria Tri; dkk. Penggunaan Media Gambar Untuk Meningkatkan Pemahaman Siswa Pada Mata Pelajaran Sosiologi. Jurnal Pendidikan Dan Pembelajaran 2, no. 3, 2013.

Zinnurain, and Abdul Gafur. Jurnal Inovasi Teknologi Pendidikan. Jurnal Inovasi Teknologi Pendidikan2,no.2,2015,http://journal.uny.ac.id/index.php/jitp\%0APENGEMBANGAN. 